\section{Growth of Government}

The Broadsheet, "The Growth of Government" (No. 417), recently issued by Political and Economic Planning, discusses briefly the main changes in the scale and character of government over the past fifty years. It provides a useful introduction to such current questions as the pressure on Ministers and senior Civil servants and the reform of administrative tribunals, as well as of other emerging problems, some of which are indicated. Reviewing first the functions and scale of government, it notes that whereas in 1901 only some 958,000 persons (including the armed forces and local government employees) out of 38 millions, or 5.8 per cent of the working population of 16 million, were in government employment, by 1950 this figure had risen to $3,214,000$, or nearly 14 per cent of the working population of 24 million, or 24 per cent if employees of the nationalized industries are included. Excluding the Post Office, the non-industrial Civil Service had increased from 28,000 established members in 1902 to 387,000 in 1955 , passing a perk of 459,000 in 1949 . Financially, it is estimated that 19 per cent of all incomes (or 29 per cent including the nationalized industries) arises in the public sector and that 10 per cent of the gross national product (plus 10 per cent for the nationalized industries) is produced in the public sector. Budget figures rose from about 8 per cent of the national income figures in 1904-5 to 24 per cent in 1919-20 and 32 per cent in 1954-55. Broadly, the government share of the working population is nearly three times, and its share o national resources at least four times, as great as in the 1900's. Local government employees increased from 375,000 in 1901 to $1,422,000$ in 1950 , the increase being mainly before 1939 , but semi-inde. pendent bodies have increased enormously; and some private, self-governing bodies, like the British Standards Institution and the Finance Corporation for Industry, have acquired a form of public status and responsibility.

\section{National Fuel Policy}

ON March 24 the Paymaster-General, Sir Ian Horobin, said in reply to a question in the House of Commons regarding the future of the coal industry that although the contributions of nuclear energy and oil are essential towards meeting our growing needs for energy, coal will remain the foundation of British fuel economy for many years. We must, therefore, have an efficient coal industry producing the grades required in the appropriate quantities and at rensonable prices. Large-scale capital investment will continue to be needed for this purpose. On March 31, Sir Ian said that the recent re-phasing of the nuclear power programme, as part of the general revision of capital investment, now provides for the installation of 5,000-6,000 MW. of capacity by the end of 1966 , and will increase the consumption of coal by power stations by three million tons a year. No further change in the programme is contemplated at present, and Sir Ian declined to add to his previous reply about capital investment in the coal industry. The whole question of energy and capital investment is periodically reviewed; but while savings are anticipated in the capital cost of nuclear power stations, no major change in the programme is warranted in the immediate future, although developments have occurred which promise to cheapen the product from such stations.

\section{Application of Science to Industry}

A LONG motion on the application of science to industry, moved by Mr. R. E. Prentice in the House of Commons on April 28, quoted the estimate of the Advisory Council for Scientific Policy that industry was only spending 0.8 per cent of its output on research and development, and referred to the affiliation of only 520 firms out of a potential 10,000 to the Production and Engineering Research Association. Mr. Prentice suggested that an attitude of self-satisfaction is still too widespread in British industry. Referring to the last two annual reports of the Department of Scientific and Industrial Research, he questioned whether Governmentfinanced research is proceeding on an adequate scale. $\mathrm{He}$ also asked whether, having regard to the expenditure on defence of 59 per cent of our total scientific research and development effort, one could be sure that priorities were right, and he suggested that overall strategy on scientific matters was lacking. From the national point of view, he believes that the Lord President of the Council or some other senior minister should have fulltime responsibility for scientific policy and the Advisory Council should be strengthened by more representatives from both sides of industry. We need an entirely new public attitude to science and its use by Government and industry. Members of Parliament could give a lead, but more attention by trades union branches is also required. Only fifteen minutes were allowed for the debate and the Parliamentary Secretary to the Board of Trade had one minute to reply.

\section{Primary Schools in the Transvaal}

IN 1953 the Department of Education of the Transvaal Provincial Administration set up a committee to report on schools building research. Already reports have been published of investi. gations made into school furniture, the selection of sites for school and hostel buildings, the layout of playing fields and grounds, and school halls. The committee has now issued a detailed report on "The Planning of Primary Schools" (Report of the School Buildings Committee, 1957. Pp. 86. Pretoria : Government Printer, 1957). This is centred on the needs of the child, and gives a clear recommendation about such topics as the most suiteble class-rooms, communal rooms and administrative offices. The types of school most suitable for one- and twostandard entry primary schools are deseribed, while detailed cost analyses are also included. The need for co-operation between all those responsible for school design is constantly stressed, particularly close co-operation between the educator, the architeet and administrative officers being advocated. Published in Afrikaans and English, the report is clearly illustrated and should serve as a guide in countries other than South Africa.

\section{South African Museum}

The annual report of the South Africen Museum for the year ending March 31, 1957 (pp. 21. Cape Town: South African Museum, 1957), records the great activity of this institution at Cape Town under the energetic guidance of the new director, Dr. A. W. Crompton. The Trustees are grateful for the increased facilities for salary adjustments, holiday bonuses and research work granted by the Minister of Education, Arts and Science-the latter is already reflected in 